Canadian University Music Review

Canadian University Music Review

Revue de musique des universités canadiennes

\title{
Arnold Whittall. Exploring Twentieth-Century Music: Tradition and Innovation. Cambridge: Cambridge University Press, 2003. xi, 238 pp. ISBN 0-521-81642-4 (hardcover)
}

\section{Brenda Ravenscroft}

Volume 23, numéro 1-2, 2003

URI : https://id.erudit.org/iderudit/1014528ar

DOI : https://doi.org/10.7202/1014528ar

Aller au sommaire du numéro

Éditeur(s)

Canadian University Music Society / Société de musique des universités canadiennes

ISSN

0710-0353 (imprimé)

2291-2436 (numérique)

Découvrir la revue

Citer ce compte rendu

Ravenscroft, B. (2003). Compte rendu de [Arnold Whittall. Exploring Twentieth-Century Music: Tradition and Innovation. Cambridge: Cambridge University Press, 2003. xi, 238 pp. ISBN 0-521-81642-4 (hardcover)]. Canadian University Music Review / Revue de musique des universités canadiennes, 23(1-2), 224-227. https://doi.org/10.7202/1014528ar

All Rights Reserved (C Canadian University Music Society / Société de musique des universités canadiennes, 2004
Ce document est protégé par la loi sur le droit d'auteur. L'utilisation des services d'Érudit (y compris la reproduction) est assujettie à sa politique d'utilisation que vous pouvez consulter en ligne.

https://apropos.erudit.org/fr/usagers/politique-dutilisation/ 
Arnold Whittall. Exploring Twentieth-Century Music: Tradition and Innovation. Cambridge: Cambridge University Press, 2003. xi, 238 pp. ISBN 0-52181642-4 (hardcover).

It was as a neophyte graduate student, fresh from the colonies, that I first encountered Arnold Whittall in the Master's program in Theory and Analysis at King's College, London. Following a brutal term of Schenkerian analysis under the cold gaze of Professor D., our class greeted the arrival of Professor Whittall in the second term with some relief. His incisive instruction in the rigours and intricacies of set theory was delivered in a disarmingly mild, faintly avuncular manner. More than his demeanour, however, what engaged us was the way in which he interspersed instruction in technical matters, such as the Z-relation and nexus sets, with conversations about the music of the century. He introduced us to the music of Michael Tippett, whose opera The Midsummer Marriage was being performed contemporaneously by the English National Opera, he provoked us to think about how the concept of modernism found form in composers such as Benjamin Britten and Elliott Carter, he discussed the ways in which aspects of musical structure may offer insights into a composer's reaction to their society and its cultural climate.

For many of us, this was our first encounter with the enriched world of ideas and interpretations that constitute musicology, having previously only been exposed to the routine description of historical events, dates and documents in "music history" courses. And for all of us, it influenced the way we thought about music of the twentieth century, and laid rest to the belief that theoretical analysis could operate independently of musical context.

It is Whittall's ability to inhabit both the realm of the analytical and the musicological that makes Exploring Twentieth-Century Music: Tradition and Innovation such a fascinating and unique book. Musical works of this century are presented not only as "expressive structures" generated by specific compositional methods and techniques, but also as objects of interpretation and meaning. Whittall skillfully blends analytical examination of specific pieces with discussion of the larger context in which they are formed by providing critical and musicological commentaries on those compositions, and by examining the fundamental forces that affected composers and their works within the complex and challenging world of the twentieth century.

Having been thinking and writing about music since the 1960s, when he published his first article, "Rousseau and the Scope of the Opera" Whittall's perspective on music of the twentieth century has been gained over a period of at least four decades. ${ }^{1}$ His career, encompassing the roles of teacher, broadcaster, concert presenter, and writer on music and music theory, has involved a detailed examination of music of the nineteenth and twentieth centuries, and his dedication to contemporary composition has made him a formative force in the world of modern music. It would not be an overstatement to say that his work has helped to shape generations of musicians, directly influencing the academic landscape in both Europe and North America.

1 Arnold Whittall, "Rousseau and the Scope of Opera," Music and Letters 45 (1964): 369-76. 
Most books about twentieth-century music take a chronological path in their presentation of the music of this century, starting with what they identify as the tipping point between high romanticism and early atonality, and organizing the rest of the century either by consecutive compositional trends-avant-garde, nationalism, neoclassicism, serialism, and so forth-or by focusing sequentially on prominent composers of the time. Books of a more technical nature tend to concentrate almost exclusively on aspects of pitch organization in the twentieth century, covering topics related to set theory, serialism, the use of alternative scales and modes, and occasionally paying brief attention to other parameters such as rhythm and texture. Whittall's view of the century is much broader, although not necessarily as comprehensive. Through investigation into the music of a group of important composers of the twentieth century, including Debussy, Webern, Schoenberg, Stravinsky, Bartók, Janáček, Britten, Carter, Birtwistle, Tippett and Andriessen, he presents a series of narratives delineating the identities and images which have shaped this music, such as classicism, modernism, secularism, ritual, mirroring, and national and musical character. These categories are interactive rather than exclusive. Not only do several composers appear in different settings, but Whittall acknowledges that many of his chapter and section titles are "interchangeable."

Not all prominent composers are included in the group, the most striking omission being Varèse, whose influential position as one of the leading European innovators is hard to circumnavigate. Whittall, from his deservedly lofty position, freely admits to an element of value judgement in his selection of materials, describing how he pared down the original title of the lecture series from which the book is derived, "The World of Twentieth-Century Music" to "My World of Twentieth-Century Music" (my emphasis), before abandoning any global version of the title as inappropriate. His disclaimer in the preface to Exploring TwentiethCentury Music states, "the text is very personal-selective, narrow, limited-in the range of composers, commentators, materials and topic considered" (p. vii), placing it at some distance from the comparative comprehensiveness of his recent text, Musical Composition in the Twentieth Century. ${ }^{2}$

Certain figures loom large in the book. Not surprisingly Schoenberg and Stravinsky, whose generative and influential powers have accumulated and been verified over the past century are foremost. Both figures pervade the text, appearing in several locations. Whittall, instead of focusing on the superficial oppositions between Schoenberg and Stravinsky, delves deeper, finding their points of contact, and showing a convergence between the two that situates them on the same modernist continuum. There is a refreshing (for North American readers) focus on British composers, particularly Tippett and Britten, a duo who attracted Whittall's critical eye over twenty years ago when he published The Music of Britten and Tippett: Studies in Themes and Techniques. ${ }^{3}$ At times, Whittall reaches back into the nineteenth century - and even earlier-in order to place a twentiethcentury composition in context. The quest for transcendence evident in the 
symphonies of Tippett and Shostakovich, for example, is viewed in light of their musical descendence from Beethoven.

The organization of Exploring Twentieth-Century Music usually pairs the music of two or more composers within each chapter, with commentary drawing in the writing of several other figures. Chapter 1 , "The work in the world," arguably the most general in scope, examines the compositional act in terms of place-nationality, location and environment. Ideas of mirroring and symmetry in the music of Debussy and Webern are presented in the second chapter, titled "Reflections, reactions," while Janáček and Bartók are allied through their use of "national accents to reduce ... their representations of pathos from associations with Austro-German expressionism" (p. 47) in "Rites of renewal and remembrance." "Transcending the secular," the fourth chapter, examines spirituality in the music of Stravinsky and Messiaen. Chapter 5 is devoted to Schoenberg, with brilliant commentary by several key writers including Theodor Adorno, Hans Kellar, Martha Hyde and Bill Benjamin, and is followed by a chapter focused on "The subject of Britten." Chapter 7, "Engagement or alienation?" inverts the idea of "characterising a composer's work in terms of a philosophy, political ideology or some other system of beliefs" (p. 108) by examining the reverse in the music of Kagel and Schnittke, while Mozart, Wagner, Henze and Britten rub shoulders in "Rites of transformation." Carter and Birtwistle form an alternating duo in the ninth chapter, "Modernism, lyricism," and Whittall returns to Carter in the final chapter of the book. Chapter 10, "Experiment and orthodoxy," focuses on the tension between tradition and innovation in the minimalist works of Andriessen and Adams. The last chapter of the book, "Modernism in retreat?" finds Whittall at a pivotal point in time. Drawing on the music of Boulez, Berio, Carter and Ligeti, he looks back at the trajectory of modernism over the century, asking whether the end of the twentieth century might also signify the end of modernism - and also looks forward, sounding a word of warning in his suggestion that "a retreat from modernism in the twenty-first century is essential if serious music is to survive" (p. 186).

The narratives in Exploring Twentieth-Century Music are centred around oppositions, complementary concepts, the balance between tendencies in music, as is readily apparent from the subtitle of the book (Tradition and Innovation) as well as from the headings of individual chapters. Early on Whittall warns against "the easy embrace of singularity at the expense of multiplicity" (p. 21), and his intellectual delight in the ambiguities and tension of contrasts inherent in most music provides the book with much of its depth. "Defiance and ambivalence" characterize Janácek, "freedom and control" combine in Cage, Webern's musical structures shift between asymmetrical set classes and symmetrical octatonic relations. These themes enhance the complexity of Whittall's insight into the music, but are occasionally vulnerable to overuse. In particular, despite Whittall's early description of the opposition between the Apollonian and Dionysian as "one of the dominant topoi of this book" (pp. 22-23), his repeated reliance on analogies involving Apollo and Dionysus start to seem contrived over the course of the book. (The index contains no fewer than twenty-nine references!) Perhaps this arises from the collective nature of the origins of the material since several sections in the book are based on earlier published writings, as well as on the lecture series. 
Whittall's erudition gleams through his elegant language and fluid writing style. The text moves seamlessly between the cultural and the technical, between the general and the specific, and the illustrative musical examples are models of clarity. The notes for each chapter are presented collectively at the end of the book, a format, while tidy, that creates some awkwardness for the reader who seeks to benefit frequently from these wonderfully informative accompaniments. The comprehensive bibliography includes most major contemporary books on twentieth-century music and its composers, and many significant journal articles.

In short, although twenty years have passed since my first encounter with Arnold Whittall, I can think of no more stimulating, persuasive and experienced a guide for an exploration into the world of twentieth-century music.

Brenda Ravenscroft

Margaret Bent and Andrew Wathey, eds. Fauvel Studies: Allegory, Chronicle, Music, and Image in Paris, Bibliothèque nationale de France, MS français 146. Oxford: Clarendon Press, 1998. xix, 666 pp. ISBN 0-19-816579-X (hardcover).

This enormous collection of essays combines the work of 27 authors, including ten musicologists, seven literary scholars, and ten historians, four of whom specialize in the history of art and architecture. Few musical manuscripts would warrant the breadth of attention and scholarly scrutiny found here, but Paris, Bibliothèque nationale, MS français 146 (henceforth Fauvel) is an indisputable exception. Dating from the first decades of the fourteenth century, this is the oldest and largest ( 93 folia, measuring $33 \times 46 \mathrm{~cm}$ ) of the thirteen extant manuscripts containing an interpolated version of the Roman de Fauvel, written by Gervès du Bus. A satirical allegory, the Roman encapsulates the last decades of the reign of the French king, Philip the Fair (d. 1314), and the downfall of his finance minister, Enguerran de Marigny, using the mocking image of a horse called Fauvel, whose name (an acrostic) and nature is representative of the vices: flaterie, avarice, vilanie, variété, envie, and lascheté. This grand literary creation, written in Ōld French and intended for a sophisticated audience, is richly decorated with both highly detailed illuminations and interpolated music. It includes settings of both French and Latin poetry, in the form of motets, conductus, and monophonic songs, early examples of the formes fixes. Also included in the manuscript are the complete works of an otherwise obscure composer, Jehannot de Lescurel, a verse chronicle of French history (1300-1316), and several French and Latin narrative dits (moralizing poems) by Geffroy de Paris. A modern edition of the Latin examples, by Leofranc Holford-Strevens, appears for the first time in the present volume ("The Latin Dits of Geffroy de Paris: An Editio Princeps"); this article alone is an unquestionably valuable contribution to the existing literature.

Any musical scholar approaching this extremely complex manuscript for the first time would do well to begin with a detailed reading of this volume, which not only handily summarizes all relevant scholarship to date (and provides a valuable introduction to the source by the volume editors) but also considerably 